\title{
Society of Surgical Oncology SSO 2020 - International Conference on Surgical Cancer Care
}

Over the past several weeks, the SSO has closely monitored reports from the World Health Organization and the Centers for Disease Control and Prevention with regard to the novel Coronavirus (COVID-19). As a result of the proliferation of the virus and recognizing the responsibility to protect the health and safety of SSO 2020 attendees, their patients and their families, the SSO Executive
Council has decided to postpone SSO 2020 to August 17-20, 2020, in Boston, Massachusetts. Updated March 6, 2020.

Publisher's Note Springer Nature remains neutral with regard to jurisdictional claims in published maps and institutional affiliations. 